\title{
Epidemiology of Functional Gastrointestinal Disorders in Japan and in the World
}

\author{
Tadayuki Oshima* and Hiroto Miwa \\ Division of Gastroenterology, Department of Internal Medicine, Hyogo College of Medicine, Hyogo, Japan
}

Functional gastrointestinal disorders (FGIDs), represented by functional dyspepsia (FD) and irritable bowel syndrome (IBS), are a group of disorders that include variable combinations of chronic or recurrent gastrointestinal symptoms not explained by structural or biochemical abnormalities. FGIDs account for a significant percentage of patients seen in primary care settings with abdominal symptoms. Although the definition of FGIDs can easily affect the prevalence, the prevalences of dyspepsia/FD and IBS diagnosed by the Rome III criteria in the general population are $5.3-20.4 \%$ and $1.1-29.2 \%$, respectively. Recent reports of FD and IBS defined by the Rome III criteria indicated a female predominance. Regarding the subtype prevalence of FD, postprandial distress syndrome was more prevalent than epigastric pain syndrome (5.6-13.9\% vs $0.9-9.5 \%)$. The subtype prevalence of IBS is characterized by male predominance for IBS with diarrhea and female predominance for IBS with constipation. Factors affecting the development of FGIDs such as epidemiological factors including genetic and environmental factors, are important. Gene polymorphisms are involved in the development of FGIDs. The prevalence differs among races and geographic areas. Foods may affect the development of FGIDs, but the causal relationships between food and FGIDs are not conclusive. The symptoms often regress and appear in the course of these entities. Building a favorable patient-doctor relationship is effective for controlling symptoms of FGIDs. Physicians should explain that FGIDs are highly prevalent conditions, impair the patients' quality of life even without evident underlying organic causes and are not life-threatening conditions to ensure patients' understanding.

(J Neurogastroenterol Motil 2015;21:320-329)

Key Words

Epidemiology; Gastrointestinal diseases; Sex

\section{Introduction}

Functional gastrointestinal disorders (FGIDs) are a group of gastrointestinal (GI) disorders that include various combinations of chronic or recurrent GI symptoms not explained by structural or biochemical abnormalities. ${ }^{1}$ Functional dyspepsia (FD) and irritable bowel syndrome (IBS) are among the most widely recognized FGIDs. It is characteristic of the FGIDs that each entity has no specific objective findings, and that they overlap with each other. Therefore, these entities are syndromes, and their diagnosis and treatment are similar. Diagnosis of FGIDs is based on

Received: December 27, 2014 Revised: January 25, 2015 Accepted: January 25, 2015

(c) This is an Open Access article distributed under the terms of the Creative Commons Attribution Non-Commercial License (http://creativecommons. org/licenses/by-nc/4.0) which permits unrestricted non-commercial use, distribution, and reproduction in any medium, provided the original work is properly cited.

${ }^{*}$ Correspondence: Tadayuki Oshima, MD, PhD

Division of Gastroenterology, Department of Internal Medicine, Hyogo College of Medicine, 1-1 Mukogawa-cho, Nishinomiya, Hyogo 663-8501, Japan

Tel: +81-798-45-6662, Fax: +81-798-45-6661, E-mail: t-oshima@hyo-med.ac.jp

Financial support: None.

Conflicts of interest: None.

Author contributions: Tadayuki Oshima collected references, summarized data, analyzed data, and prepared manuscript, and Hiroto Miwa supervised the preparation of the manuscript.

ORCID: Tadayuki Oshima, http://orcid.org/0000-0001-6949-932X. 
patients' self-reported symptoms. Therefore, the definition of the symptoms may differ by countries and geographic areas. The pathophysiology of FGIDs is recently becoming clearer. The definition and the diagnostic criteria have been revised, and the diagnostic system is becoming more systematic. ${ }^{1,2}$ In this review, the epidemiology of FGIDs in Japan and in the world is reviewed.

\section{Prevalence}

It is well-known that dyspeptic symptoms occur with organic diseases such as reflux esophagitis, gastroduodenal ulcer, and cancer. However, dyspepsia without organic disease is more prevalent in patients who seek medical care. ${ }^{3}$ El-Serag et $\mathrm{al}^{4}$ performed a meta-analysis of the literature published between 1976 and 2000 that showed the frequency of dyspepsia to be $10-40 \%$; however, this frequency was $5-12 \%$ when concurrent symptoms including heartburn were excluded. In the Rome II definition published in $1999,{ }^{2}$ reflux symptoms were excluded from the definition of FD, and when IBS symptoms were present, FD was diagnosed as IBS. Therefore, whether heartburn or IBS is included easily affects the prevalence of FD. Kawamura et $\mathrm{al}^{5}$ reported that the prevalence of FD defined by Rome II in subjects undergoing a health check-up was $13 \%$ when organic diseases were excluded. Shaib et $\mathrm{al}^{6}$ also reported that the prevalence of FD was $15 \%$ when organic diseases were excluded by endoscopy and when subjects with gastroesophageal reflux disease symptoms were excluded. In a report from England, when endoscopy was performed in $20 \%$ of patients to exclude organic diseases, the prevalence of FD was thought to be $11.5 \%$. $^{7}$ In a report from Norway, when endoscopy was performed in almost all patients, the prevalence of FD was $14.7 \%{ }^{8}$

The prevalence of uninvestigated dyspepsia or $\mathrm{FD}$ in the general population, diagnosed by Rome III criteria, which has been used from 2006, has been reported to be 5.3-20.4\% (Table 1). ${ }^{9-22}$ Hongo et $\mathrm{al}^{23}$ reported that organic lesions were found in only $9 \%$ of patients examined by endoscopy because of dyspepsia symptoms. Furthermore, among those without any specific lesions detected on endoscopy, GI symptoms were resolved within one week after the endoscopy in $28 \%$ of patients before initiating medication. Okumura et $\mathrm{al}^{3}$ reported that $21 \%$ of patients who visited a university hospital with abdominal symptoms had FD.

We also recently performed an Internet survey using a registered panel in Japan to elucidate the prevalence of dyspepsia and childhood abuse history in the population. ${ }^{24}$ When we estimated the prevalence of dyspepsia using our age-stratified subjects' data and the Japanese population census (http://www.stat.go.jp/english/data/kokusei/index.htm), the prevalence of dyspepsia in Japan

Table 1. Prevalence of Fucntional Dyspepsia (Rome III Criteria)

\begin{tabular}{|c|c|c|c|c|c|c|c|c|c|c|c|c|}
\hline \multirow[b]{2}{*}{ Study } & \multirow{2}{*}{$\begin{array}{l}\text { Sample } \\
\text { size }\end{array}$} & \multirow{2}{*}{$\begin{array}{l}\text { Subject group } \\
\text { (Method of } \\
\text { data collection) }\end{array}$} & \multirow[b]{2}{*}{ Country } & \multirow[b]{2}{*}{ Age } & \multicolumn{6}{|c|}{ Prevalence (\%) } & \multicolumn{2}{|c|}{$\mathrm{UD} / \mathrm{FD}(\%)^{2}$} \\
\hline & & & & & UD & FD & EPS & PDS & IBS & $\begin{array}{c}\text { Overlap } \\
\text { (FD/IBS) }\end{array}$ & M & $\mathrm{F}$ \\
\hline Aro et al, ${ }^{9} 2009$ & 1001 & GP (Postal) & Sweden & $20-80$ & 20.2 & 15.7 & 5.2 & 12.2 & - & - & 13.5 & 26.5 \\
\hline Barzkar et al, ${ }^{10} 2009$ & 18180 & GP (Interview) & Iran & $16-80$ & 8.5 & - & - & - & 8.3 & - & 6.1 & 10.9 \\
\hline Kaji et al, ${ }^{11} 2010$ & 2680 & Health check-up & Japan & mean 40 & 10.0 & - & - & - & 14.2 & 3.4 & - & - \\
\hline Noh et al, ${ }^{12} 2010$ & 2388 & Health check-up & Korea & mean 43 & - & 8.1 & - & - & 10.1 & - & - & - \\
\hline Zagari et al, ${ }^{13} 2010$ & 1033 & GP (Postal) & Italy & $32-84$ & 15.1 & 11.0 & 8.8 & 6.3 & - & - & 12.5 & 17.8 \\
\hline Chang et al, ${ }^{14} 2012$ & 4275 & GP (Interview) & Taiwan & $19 \leq$ & 5.3 & - & - & - & 4.4 & 0.3 & 4.4 & 6.3 \\
\hline Choung et al, ${ }^{15} 2012$ & 3517 & GP (Postal) & USA & mean 61 & 9.8 & - & - & - & 19.4 & 5.2 & 6.2 & 12.8 \\
\hline Mak et al, ${ }^{16} 2012$ & 2011 & GP (Telephone) & China & $15-65$ & 8.0 & - & 0.9 & 6.9 & - & - & 6.9 & 8.9 \\
\hline Matsuzaki et al, ${ }^{17} 2012$ & 8038 & GP (Internet) & Japan & $20-65$ & 12.8 & 7.0 & 2.3 & 6.2 & - & - & 6.6 & 7.3 \\
\hline Miwa, $^{18} 2012$ & 15000 & GP (Internet) & Japan & $20-79$ & 6.5 & - & - & - & 14.0 & 3.0 & $\mathrm{M}<\mathrm{F}$ & \\
\hline Kim et al, ${ }^{19} 2014$ & 3399 & Health check-up & Korea & $15-98$ & - & 20.4 & 9.5 & 13.9 & - & - & 17.5 & 24.0 \\
\hline Min et $\mathrm{al}^{20} 2014$ & 5000 & GP (Telephone) & Korea & $20-69$ & 7.7 & - & 4.2 & 5.6 & 3.5 & 1.9 & 5.9 & 9.5 \\
\hline Perveen et al, 2014 & 3000 & GP (Interview) & Bangladesh & $15-97$ & 8.3 & - & 6.0 & 6.8 & 12.9 & 3.5 & 8.7 & 8.0 \\
\hline Rasmussen et al, 22014 & 47090 & GP (Internet) & Denmark & $20 \leq$ & 7.7 & - & - & - & 10.5 & 2.9 & 6.4 & 8.8 \\
\hline
\end{tabular}

${ }^{\mathrm{a}}$ Prevalence in male (M) and female (F) (\%), including the calculated data from papers.

UD, uninvestigated dyspepsia; FD, functional dyspepsia; EPS, epigastric pain syndrome; PDS, postprandial distress syndrome; GP, general population; -, not assessed. 
was estimated to be $21.9 \%$, and the percentage of subjects who consulted a medical institute was only $5.7 \%$ of the Japanese population. ${ }^{25}$ In other words, only one-fourth of dyspeptic subjects visited a medical institute. As the usefulness of an Internet survey was not validated, these conclusions are not firm. With the recent advances of Internet applications, online surveys may be useful as a tool to estimate the prevalence, especially in the general population.

IBS is a functional bowel disorder in which abdominal pain or discomfort is associated with defecation or a change in bowel habit and with features of disordered defecation. ${ }^{26}$ In a systematic review of IBS in North America, the prevalence of IBS ranged from $3 \%$ to $20 \%$, with most estimates ranging from $10 \%$ to $15 \% .^{27}$ Reports from Japan indicated that the prevalence of IBS defined by Rome II was $6.1 \%$ to $35.5 \%$. In reports using Rome III criteria, the prevalence of IBS was $1.1 \%$ to $29.2 \%$ (Table 2). ${ }^{11,12,14,15,18,21,22,28-38}$ Miwa $^{29}$ reported that the prevalence of IBS was $13.1 \%$ (male $10.7 \%$ and female $15.5 \%$ ), and when the prevalence of IBS was evaluated using Rome II criteria in the same cohort, IBS prevalence was $9.8 \%$, suggesting that the Rome III criteria are better for picking up more masked IBS cases.

The prevalences of FGIDs other than FD and IBS in the general population were investigated in few studies. Only two reports investigated the prevalence of functional bowel disorders, including functional abdominal bloating, functional constipation (FC), functional diarrhea, unspecified functional bowel disorder (UFBD), and functional abdominal pain syndrome (FAPS) defined by Rome III criteria (Table 3). ${ }^{14,33}$ These two reports showed female predominance of FC and UFBD. Among these FGIDs, UFBD, uninvestigated dyspepsia, and FC were common, and FAPS was less common than other FGIDs. This is consistent with a report of hospital outpatients in Japan. ${ }^{39}$

The investigation environment, the definition of symptom duration, and the accuracy of excluding organic diseases have all been identified as factors affecting the prevalence of FGIDs. In the Rome II definition, ${ }^{2}$ the symptom duration of FD and IBS was defined as at least 12 weeks during the preceding 12 months, and in Rome III, ${ }^{1}$ at least 3 months with symptom onset at least 6

Table 2. Prevalence of Irritable Bowel Syndrome (Rome III Criteria)

\begin{tabular}{|c|c|c|c|c|c|c|c|c|c|c|c|}
\hline \multirow[b]{2}{*}{ Study } & \multirow{2}{*}{$\begin{array}{l}\text { Sample } \\
\text { size }\end{array}$} & \multirow{2}{*}{$\begin{array}{l}\text { Subject group } \\
\text { (Method of } \\
\text { data collection) }\end{array}$} & \multirow[b]{2}{*}{ Country } & \multirow[b]{2}{*}{ Age } & \multicolumn{3}{|c|}{$\operatorname{IBS}(\%)^{\mathrm{a}}$} & \multicolumn{4}{|c|}{ Subtype $(\%)^{\mathrm{a}}$} \\
\hline & & & & & Total & M & $\mathrm{F}$ & IBS-C & IBS-D & IBS-M & IBS-U \\
\hline Jung et al, ${ }^{28} 2007$ & 2273 & GP (Postal) & USA & $33-93$ & 11.1 & 7.9 & 13.9 & 3.2 & 3.9 & 1.3 & 2.7 \\
\hline Miwa, $^{29} 2008$ & 10000 & GP (Internet) & Japan & $20 \leq$ & 13.1 & 10.7 & 15.5 & 3.1 & 3.9 & 6.1 & - \\
\hline Gomez Alvarez et al, ${ }^{30} 2009^{\mathrm{b}}$ & 558 & GP (Interview) & Colombia & $18-60$ & 19.9 & - & - & - & - & - & - \\
\hline 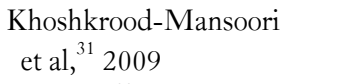 & 18180 & GP (Interview) & Iran & $16 \leq$ & 1.1 & 0.6 & 1.5 & - & - & - & - \\
\hline Lee et al, ${ }^{32} 2009$ & 2005 & GP (Telephone) & China & $15-65$ & 5.4 & 4.6 & 6.2 & 1.1 & 2.0 & 0.3 & 1.9 \\
\hline Kaji et al, ${ }^{11} 2010$ & 2680 & Health check-up & Japan & Mean 40 & 14.2 & - & - & - & - & - & - \\
\hline Noh et al, ${ }^{12} 2010$ & 2388 & Health check-up & Korea & Mean 43 & 10.1 & - & - & - & - & - & - \\
\hline Sorouri et al, ${ }^{33} 2010$ & 18180 & GP (Interview) & Iran & $16-80$ & 1.1 & 0.6 & 1.5 & - & - & - & - \\
\hline Ebling et al, ${ }^{34} 2011$ & 703 & GP (Postal) & Croatia & $20-69$ & 29.2 & 21.4 & 36.7 & - & - & - & - \\
\hline Kubo et al, ${ }^{35} 2011$ & 2717 & Health check-up & Japan & Mean 40 & 13.5 & 10.5 & 19.3 & 2.9 & 3.8 & 3.3 & 3.6 \\
\hline Makharia et al, ${ }^{36} 2011$ & 4767 & GP (Interview) & India & $18-64$ & 4.0 & 3.2 & 4.8 & 0.3 & 1.5 & 1.7 & 0.5 \\
\hline Chang et al, ${ }^{14} 2012$ & 4275 & GP (Interview) & Taiwan & $19 \leq$ & 4.4 & 3.4 & 5.4 & - & - & - & - \\
\hline Choung et $\mathrm{al}^{15}{ }^{15} 2012$ & 3517 & GP (Postal) & USA & Mean 61 & 19.4 & - & - & - & - & - & - \\
\hline Miwa $^{18} 2012$ & 15000 & GP (Internet) & Japan & 20-79 & 14.0 & 12.7 & 15.4 & - & - & - & - \\
\hline Krogsgaard et al, ${ }^{37} 2013$ & 6112 & GP (Internet) & Denmark & $18-50$ & 16.0 & & & 2.9 & 5.3 & 5.7 & 1.8 \\
\hline Lin et $\mathrm{al}^{38} 2014$ & 1002 & GP (Interview) & UK & $16-93$ & 6.0 & & $\mathrm{~F}$ & 0.7 & 1.4 & 2.7 & 1.2 \\
\hline Perveen et al, ${ }^{21} 2014$ & 3000 & GP (Interview) & Bangladesh & $15-97$ & 12.9 & 12.4 & 13.6 & 3.5 & 4.5 & 3.7 & 0.6 \\
\hline Rasmussen et al, 2014 & 47090 & GP (Internet) & Denmark & $20 \leq$ & 10.5 & 7.9 & 12.8 & - & - & - & - \\
\hline
\end{tabular}

${ }^{\mathrm{a}}$ Including the calculated data from papers, ${ }^{\mathrm{b}}$ Spanish (English abstract).

IBS, irritable bowel syndrome; M, male; F, female; IBS-C, IBS with constipation; IBS-D, IBS with diarrhea IBS-M, mixed IBS; IBS-U, unsubtyped IBS; GP, general population; -, not assessed. 
Table 3. Prevalence of Functional Gastrointestinal Dyspepsia (Rome III Criteria)

\begin{tabular}{|c|c|c|c|c|c|c|c|c|c|c|c|}
\hline \multirow[b]{2}{*}{ Study } & \multirow{2}{*}{$\begin{array}{l}\text { Sample } \\
\text { size }\end{array}$} & \multirow{2}{*}{$\begin{array}{l}\text { Subject group } \\
\text { (Method of } \\
\text { data collection) }\end{array}$} & \multirow[b]{2}{*}{ Country } & \multirow[b]{2}{*}{ Age } & \multicolumn{7}{|c|}{ PrevalenceTotal (M/F) (\%) } \\
\hline & & & & & UD & IBS & $\mathrm{AB}$ & Constipation & Diarrhea & UBD & APS \\
\hline Sorouri et al, ${ }^{33} 2010$ & 18180 & GP (Interview) & Iran & $16-80$ & $\begin{array}{l}8.9 \\
(-/-)\end{array}$ & $\begin{array}{c}1.1 \\
(0.6 / 1.5)\end{array}$ & $\begin{array}{c}1.5 \\
(1.4 / 1.7)\end{array}$ & $\begin{array}{c}2.4 \\
(1.2 / 3.7)\end{array}$ & $\begin{array}{c}0.2 \\
(0.2 / 0.3)\end{array}$ & $\begin{array}{c}5.5 \\
(4.3 / 6.7)\end{array}$ & - \\
\hline Chang et al, ${ }^{14} 2012$ & 4275 & GP (Interview) & Taiwan & $19 \leq$ & $\begin{array}{c}5.3 \\
(4.4 / 6.3)\end{array}$ & $\begin{array}{c}4.4 \\
(3.4 / 5.4)\end{array}$ & $\begin{array}{c}2.1 \\
(1.3 / 3.0)\end{array}$ & $\begin{array}{c}4.4 \\
(2.8 / 6.2)\end{array}$ & $\begin{array}{c}2.2 \\
(2.7 / 1.7)\end{array}$ & $\begin{array}{c}8.9 \\
(7.6 / 10.2)\end{array}$ & $\begin{array}{c}0.4 \\
(0.2 / 0.5)\end{array}$ \\
\hline
\end{tabular}

M, male; F, female; UD, uninvestigated dyspepsia; IBS, irritable bowel syndrome; AB, abdominal bloating UBD, unspecified bowel disorder; APS, abdominal pain syndrome; GP, general population; -, not assessed.

months prior to diagnosis, which implies that the duration of symptoms can easily change the prevalence. In Japan, people who have symptoms visit a medical institute within less than 6 months of symptom onset because access to facilities is easy. ${ }^{40,41}$ Thus, the duration of symptoms does not match the criteria of FD in the majority of cases. ${ }^{40,42}$ Furthermore, although structural or biochemical disorders should be excluded, they are not easy to exclude in a survey of the general population. In a large-scale analysis of the prevalence of FGIDs, it is not easy to perform examinations of all subjects. In general practice, the availability of examinations may be limited and different compared to those in a large hospital or university hospital. The characteristics of patients are also different in primary care and tertiary care settings. When new patients who visited primary clinics and tertiary care hospitals with gastrointestinal symptoms for more than 6 months in Korea were analyzed, the prevalences of FD and IBS defined by Rome III criteria were $46.0 \%$ and $40.2 \%$, respectively. ${ }^{43}$ On the other hand, when patients who visited a general hospital in Japan were analyzed, the prevalences of FD and IBS defined by Rome III criteria were $2.1 \%$ and $2.4 \%$, respectively. ${ }^{39}$ Therefore, when we evaluate the prevalence of FGIDs, we should take the background characteristics of the analyzed subjects into account.

\section{Epidemiological Factors}

\section{Sex/Subtype/Age}

The prevalence of abdominal symptoms in a population-based study in the USA showed no significant differences between men and women. ${ }^{44}$ Even in Japan, no difference in the prevalence of non-ulcer dyspepsia has been reported. The definition of dyspepsia may easily affect the prevalence, and the surveys using Rome II or other than Rome definitions mostly showed no differences between men and women in the prevalence of dyspepsia., 3
However, Schlemper et $\mathrm{al}^{46}$ assessed dyspeptic symptoms present during more than 7 days per 3 months in a working population and reported that, in Japanese men and women, the non-ulcer dyspepsia rates were $11 \%$ and $26 \%$, while in The Netherlands, they were $12 \%$ and $21 \%$, respectively, indicating that dyspepsia is more prevalent in women. A report from Belgium also showed that female FD was more prevalent in consecutive patients who visited a general gastroenterology outpatient clinic. ${ }^{47}$ In a population-based study of the Icelandic population, FD was diagnosed in $12.3 \%$ of males and $20.2 \%$ of females, and it was significantly more common in females. ${ }^{47,48}$ Furthermore, in a systematic review by Ahlawat et al, ${ }^{49}$ dyspepsia had a different pattern of symptoms in men and women. ${ }^{49}$ In this manner, study area, type of survey, and the definition of FD might easily affect the results.

Approximately two-thirds of IBS patients are female, and the prevalence of IBS in females is thought to be $14-24 \% .^{50}$ The potential role of sex hormones in sex differences in the epidemiology of IBS patients has been proposed based on the female predominance, as well as the correlation between IBS symptoms and hormonal status. ${ }^{51}$ Even in Japanese studies, female predominance has been reported. ${ }^{52,53}$ Recent reports of FD and IBS defined by Rome III criteria also indicated a female predominance in Japan and other countries (Tables 1 and 2).

Regarding the subtype prevalence of FD defined by Rome II criteria, in Japanese health check-up subjects, dyspeptic symptoms were present in $17 \%$, and approximately $10 \%$ of subjects complained of dysmotility-like dyspepsia corresponding to postprandial distress syndrome (PDS), and approximately $4 \%$ of subjects complained of ulcer-like dyspepsia corresponding to epigastric pain syndrome (EPS). ${ }^{54}$ Even in a recent report using Rome III criteria, PDS was more prevalent than EPS in Sweden, China, and Japan (Table 1). ${ }^{16,17,55}$ However, a report from Italy indicated that EPS was more prevalent than PDS (Table 1). ${ }^{13}$ 
These differences by geographic areas were also reported in a review of dyspepsia defined by Rome II criteria. ${ }^{56}$ Therefore, considering these epidemiological differences of FD subtypes between Western countries and East Asia, the optimal treatment strategies for FD may differ among countries.

On the other hand, with respect to the subtype prevalence of IBS, IBS with diarrhea (IBS-D) is more predominant than IBS with constipation (IBS-C) (Table 2). The subtype prevalence of IBS is characterized by male predominance in IBS-D and female predominance in IBS-C. ${ }^{52,57}$ In a meta-analysis, women were at slightly higher risk for IBS than men. ${ }^{58}$ When the prevalence of IBS and its subtypes was determined using Rome III criteria, the prevalences of IBS subtypes in Japanese were as follows: IBS-D, male $47 \%$ and female $17 \%$; IBS-C, male $9 \%$ and female $34 \%$; and mixed IBS (IBS-M), male $44 \%$ and female $49 \% .^{29}$ IBS is most prevalent in patients 20 to 30 years old, and this prevalence decreases with age. ${ }^{58}$ In a Japanese study of medical and nursing students, the prevalence of IBS was $35.5 \%$, and students with IBS symptoms were more prone to have anxiety and depression, indicating that stress is involved in the development of IBS symptoms. ${ }^{59}$ Furthermore, high socioeconomic status may be related to the prevalence of IBS, but this is not conclusive. ${ }^{58}$

\section{Race/Geographic Area}

The domestic international gastroenterology surveillance study (DIGEST) investigated the prevalence and economic/qualityof-life impact of uninvestigated dyspepsia over 3 months and found that $41 \%$ of the general population had dyspepsia in 7 international sites, $60 \%$ in the USA, and $26 \%$ in Japan, indicating that the Japanese prevalence is relatively low. ${ }^{60}$ On the other hand, reports of dyspepsia prevalence in the general population from Australia and China showed that $24.4 \%$ and $23.5 \%$ had dyspepsia, respectively. ${ }^{61,62}$ Although these data indicate that the prevalence differs among geographic areas, the studies may not have completely excluded organic diseases, and the definition of symptom frequency was different in the reports. Furthermore, the interpretation of symptoms may be subtly different in countries and geographic areas. As the definition of FGIDs differs in the Rome III criteria, the Rome II criteria, and previous definitions, it is not easy to compare the data directly.

In an analysis performed in the USA, the prevalence of FD was not different by race. ${ }^{6}$ On the other hand, race may affect the development of IBS. The prevalence of IBS was $13.1 \%$ in Caucasians and $7.9 \%$ in Africans. ${ }^{63}$ A meta-analysis of the global prevalence of IBS indicated that the prevalence of IBS varied among countries. ${ }^{58}$

\section{Food}

FD patients do not usually eat their meals 3 times a day, and the intakes of fat, glucose, and vitamin $\mathrm{C}$ are less in female FD patients. ${ }^{64}$ However, it is also reported that the patterns of food and meal intake were not different, ${ }^{65}$ indicating that the relationship between food and FD is not clear. Since it is not known if the difference in the food intake pattern in controls and FD is the result of attempting to prevent the development of symptoms or the cause of symptoms, further studies are needed to elucidate the causal relationship.

In IBS patients, food may exacerbate symptoms. Milk, wheat, eggs, and foods high in salicylates or amines are identified as causes of exacerbation of IBS symptoms. ${ }^{66}$ Japanese IBS patients have significantly more irregular meal habits. ${ }^{67}$ Recent studies from Australia and the United Kingdom (UK) indicated that dietary restriction of fermentable oligo-, di-, and monosaccharides and polyols (FODMAPs) is effective for the treatment of IBS. ${ }^{68-71}$ Khan et $\mathrm{al}^{72}$ summarized the clinical efficacy of a low-FODMAP diet in IBS patients. A low-FODMAP diet improved self-assessed satisfaction with stool consistency in both IBS-D and IBS-C subgroups, but not in healthy controls. ${ }^{71}$ However, further studies are needed to evaluate the mechanisms of these effects. Since the daily diet differs among countries, the efficacy of a low-FODMAP diet should be evaluated in each country.

Lactose intolerance and IBS can occur at the same time in a person, but they are separate conditions that should be treated differently. A recent National Institutes of Health (NIH) conference defined "lactose intolerance as the onset of GI symptoms following a blinded, single-dose challenge of ingested lactose by an individual with lactose malabsorption, which are not observed when the person ingests an indistinguishable placebo." ${ }^{73}$ The risk of lactose intolerance is related to the dose of lactose ingested and intestinal gas production and is increased in patients with IBS-D. ${ }^{74}$ Although it is not easy to exclude lactose intolerance in daily clinical practice, it should not be included in IBS.

\section{Genetics and Early Life Events}

After the unveiling of whole human genome sequences in 2004 , it became clear in many diseases, including malignant tumors, hypertension, and psychosomatic diseases, that single nucleotide polymorphisms of genes were involved even in drug metabolism. In other words, when a single nucleotide is different, 
translation of a protein or function can easily be changed, and these changes may affect the development of diseases and treatment effectiveness.

Even in FGIDs, these gene polymorphisms are involved in the development of diseases. Syndromes of FGIDs had been thought to be difficult to explain with gene polymorphisms as the pathophysiology. However, it recently became clear that not only environmental factors, but also genetics are involved in the development of FGIDs. ${ }^{75,76}$ Levy et $^{75}$ analyzed 6060 twin pairs, and concordance for IBS was significantly greater in monozygotic (17.2\%) than in dizygotic (8.4\%) twins, supporting a genetic contribution to IBS. Even in FD patients, familial aggregations have been identified. ${ }^{77}$ As the gene polymorphisms that are involved in the development of IBS, 5-HTTLPR of serotonin transporter (SERT), TNF- $\alpha$, and $I L-10$ have been suggested. ${ }^{78,79}$ Furthermore, TLR9, IL-6, and CDH1 variants are independent risk factors of post-infectious IBS. ${ }^{80}$ The $\mathrm{C} / \mathrm{C}$ genotype of the $-42 \mathrm{C}>\mathrm{T}$ polymorphism in HTR3A, compared with $\mathrm{T}$ carrier status, is associated with the severity of IBS symptoms. ${ }^{81}$ The gene polymorphism of 5-HTTLPR is related to the development of IBS-D in females. ${ }^{82}$-HTTLPR LS/SS genotype is also associated with both increased pain sensation and increased rectal compliance. ${ }^{83}$ Serotonin is produced in the GI tract, brain, and neuronal cells, and is involved in GI motility and sensation. SERT regulates the amount of serotonin, and the $\mathrm{S} / \mathrm{S}$ allele is associated with lower expression of SERT than the L/L allele, with serotonin absorption being half that of the $\mathrm{L} / \mathrm{L}$ allele. ${ }^{84}$ This gene is also called the anxiety gene, and the distribution of this gene allele is different among races. Japanese have a great predominance of the $\mathrm{S} / \mathrm{S}$ allele compared to Caucasians. This may cause race-based differences in temperament. Therefore, it is important to realize that some gene polymorphisms are different in both pathophysiological conditions and races.

In FD, Holtmann et $\mathrm{al}^{85}$ showed for the first time that $G$-protein beta $3(G N \beta 3) \mathrm{C} 825 \mathrm{~T}$ polymorphisms are related to the development of $\mathrm{FD}$ in 2004 . The odds ratio for upper abdominal symptoms associated with the CC genotype was 2.2 compared with subjects with TC and TT genotype carrying an allele. Homozygous $G N \beta 3$ 825C carrier status is associated with unexplained predominantly upper abdominal symptoms. G-proteins are essential for stimulus-response coupling of receptors that are linked to intracellular effector systems. Approximately $80 \%$ of all known membrane receptors transduce their signals via heterotrimeric G-proteins. This polymorphism is known to affect many kinds of diseases, including hypertension. Camilleri et $\mathrm{al}^{86}$ reported that meal-unrelated dyspepsia in a USA community study was associated with the homozygous $825 \mathrm{~T}$ or $\mathrm{C}$ alleles of $G N \beta 3$. We also analyzed this polymorphism in the Japanese population. Although GN $33 \mathrm{C} 825 \mathrm{~T}$ polymorphism was not associated with FD subjects overall, interestingly, the $G N \beta 3$ subunit 825 TT genotype was associated with epigastric pain syndrome-like dyspepsia. ${ }^{87}$ These data were consistent with the report that the GN $\beta 3$ subunit $825 \mathrm{TT}$ genotype was associated with FD without Helicobacter pylori infection in Japan. ${ }^{88}$ Even in a report from The Netherlands, FD in the tertiary referral setting was associated with the $825 \mathrm{~T}$ allele of the GN $\beta 3$ gene. ${ }^{89}$ The $G N \beta 3 \mathrm{C} 825 \mathrm{~T}$ polymorphism has also been analyzed in patients with lower FGIDs, including IBS. However, no association has been shown in these diseases. ${ }^{90}$

We also analyzed the association between SERT gene (SLC6A4) polymorphism and FD. We found that the 5-HTTLPR L allele affects susceptibility to PDS. ${ }^{91}$ On the other hand, Camilleri et $\mathrm{al}^{86}$ and van Lelyveld et $\mathrm{al}^{89}$ did not show a relationship between SERT polymorphism and FD. These discrepancies may also be related to the difference in allele frequencies among races. In all FD, the CC genotype of TRPV1G315C polymorphism, and the gene polymorphisms of the tetrodotoxin resistant sodium channel $\mathrm{NaV} 1.8$, encoded by $S C N 10 A$ were the only positive polymorphisms preventing the development of $\mathrm{FD} .{ }^{92,93}$

These data indicate that genetic factors are involved in the development of FGIDs. However, the odds ratio that can be acquired by these polymorphisms is maximally two to three. We need further evaluation of how these genetic factors and other circumstantial factors interact. Environmental factors affect their development. Children of mothers with IBS have more non-GI, as well as GI, symptoms. ${ }^{94}$ When the parents have IBS, the risk of the development of IBS in their children is high, and the concordance between mothers and children was greater than the concordance between monozygotic twins, ${ }^{75}$ indicating that not only genetic factors, but also parental behaviors affect their children. ${ }^{95}$ Childhood abuse is associated with the development and exacerbation of IBS and the development of dyspepsia. ${ }^{24,96-98}$ These are also environmental factors related to the development of FGIDs.

\section{Natural Course of Functional Gastrointestinal Disorders}

As for the natural course of $\mathrm{FD}$, the dyspeptic symptoms disappear in $50 \%$ of patients after several years. ${ }^{4}$ Even in IBS pa- 
tients, $40 \%$ of patients are not diagnosed as having IBS one year later. ${ }^{27}$ Although the prevalences of FD and IBS were stable over 12-20 months, there was considerable turnover, with approximately half of those with FD and IBS on the first survey not having these symptoms on the second survey. ${ }^{99}$ Another report using Rome II criteria also indicated that the proportion of subjects in a subgroup of IBS remained the same over a year, and more than $75 \%$ of subjects changed to either of the other 2 subtypes at least once. $^{100}$ IBS-M was the least stable diagnosis (only $4.9 \%$ remained in the original classification). Transitions between IBS-M and IBS-C were more likely than between IBS-D and IBS-M.

Halder et $\mathrm{al}^{101}$ reported the natural history of FGIDs in a US population. In a prospective cohort followed for 12 years, approximately $20 \%$ had the same symptoms among people with symptoms at baseline, $40 \%$ had no symptoms, and $40 \%$ had different symptoms at follow-up. In uninvestigated dyspepsia, IBS-C, IBS-D, IBS-M, constipation, and diarrhea, the disappearance rate of each FGID between the initial and final surveys was $67 \%$, $60 \%, 60 \%, 47 \%, 78 \%$, and $71 \%$, respectively. The feature that symptoms shift among FGIDs and disappear might also be characteristic of FGIDs.

In a large-scale survey in Japan, the symptoms of FD patients with symptoms at least twice a week regressed in one-third of patients after they were told that they had no organic disease based on examinations including endoscopy and of the pathophysiological basis of FD. ${ }^{102}$ These data indicate that explanation of the condition to patients affects the symptoms of patients with FD, and that building a favorable doctor-patient relationship is effective for controlling symptoms of FD.

\section{Conclusions}

It is well-known that FGIDs represent the most prevalent condition in patients who come to medical institutions with abdominal symptoms. Determining the etiology of these patients is important to establish the treatment strategy in the primary care setting.

Although the definitions of FGIDs can easily change their prevalence, there is no doubt that we often see FGID patients in the outpatient clinic. If we do not care for these patients appropriately, physicians and staff cannot establish good relationships with them, and patients will continue with doctor shopping. Regardless of the definition of FGID, physicians should explain the condition and ensure that patients have a satisfactory under- standing of their disease.

\section{References}

1. Drossman DA. The functional gastrointestinal disorders and the Rome III process. Gastroenterology 2006;130:1377-1390.

2. Thompson WG, Longstreth GF, Drossman DA, Heaton KW, Irvine EJ, Müller-Lissner SA. Functional bowel disorders and functional abdominal pain. Gut 1999;45(suppl 2):II43- II47.

3. Okumura T, Tanno S, Ohhira M, Tanno S. Prevalence of functional dyspepsia in an outpatient clinic with primary care physicians in Japan. J Gastroenterol 2010;45:187-194.

4. El-Serag HB, Talley NJ. Systemic review: the prevalence and clinical course of functional dyspepsia. Aliment Pharmacol Ther 2004;19:643-654.

5. Kawamura A, Adachi K, Takashima T, et al. Prevalence of functional dyspepsia and its relationship with Helicobacter pylori infection in a Japanese population. J Gastroenterol Hepatol 2001;16: 384-388.

6. Shaib Y, El-Serag HB. The prevalence and risk factors of functional dyspepsia in a multiethnic population in the United States. Am J Gastroenterol 2004;99:2210-2216.

7. Jones R, Lydeard S. Prevalence of symptoms of dyspepsia in the community. BMJ 1989;298:30-32.

8. Bernersen B, Johnsen R, Straume B. Non-ulcer dyspepsia and peptic ulcer: the distribution in a population and their relation to risk factors. Gut 1996;38:822-825.

9. Aro P, Talley NJ, Ronkainen J, et al. Anxiety is associated with uninvestigated and functional dyspepsia (Rome III criteria) in a Swedish population-based study. Gastroenterology 2009;137:94-100.

10. Barzkar M, Pourhoseingholi MA, Habibi M, et al. Uninvestigated dyspepsia and its related factors in an Iranian community. Saudi Med J 2009;30:397-402.

11. Kaji M, Fujiwara Y, Shiba M, et al. Prevalence of overlaps between GERD, FD and IBS and impact on health-related quality of life. J Gastroenterol Hepatol 2010;25:1151-1156.

12. Noh YW, Jung HK, Kim SE, Jung SA. Overlap of erosive and non-erosive reflux diseases with functional gastrointestinal disorders according to Rome III criteria. J Neurogastroenterol Motil 2010; 16:148-156.

13. Zagari RM, Law GR, Fuccio L, et al. Epidemiology of functional dyspepsia and subgroups in the Italian general population: an endoscopic study. Gastroenterology 2010;138:1302-1311.

14. Chang FY, Chen PH, Wu TC, et al. Prevalence of functional gastrointestinal disorders in Taiwan: questionnaire-based survey for adults based on the Rome III criteria. Asia Pac J Clin Nutr 2012;21:594-600.

15. Choung RS, Locke GR 3rd, Schleck CD, Zinsmeister AR, Talley NJ. Overlap of dyspepsia and gastroesophageal reflux in the general population: one disease or distinct entities? Neurogastroenterol Motil 2012;24:229-234, e106.

16. Mak AD, Wu JC, Chan Y, Chan FK, Sung JJ, Lee S. Dyspepsia is strongly associated with major depression and generalised anxiety disorder - a community study. Aliment Pharmacol Ther 2012;36: 800-810. 
17. Matsuzaki J, Suzuki H, Asakura K, et al. Classification of functional dyspepsia based on concomitant bowel symptoms. Neurogastroenterol Motil 2012;24:325-e164.

18. Miwa H. Life style in persons with functional gastrointestinal disorders--large-scale internet survey of lifestyle in Japan. Neurogastroenterol Motil 2012;24:464-471, e217.

19. Kim SE, Park HK, Kim N, et al. Prevalence and risk factors of functional dyspepsia: a nationwide multicenter prospective study in Korea. J Clin Gastroenterol 2014;48:e12-e18.

20. Min BH, Huh KC, Jung HK, et al. Prevalence of uninvestigated dyspepsia and gastroesophageal reflux disease in Korea: a population-based study using the Rome III criteria. Dig Dis Sci 2014; 59:2721-2729.

21. Perveen I, Rahman MM, Saha M, Rahman MM, Hasan MQ. Prevalence of irritable bowel syndrome and functional dyspepsia, overlapping symptoms, and associated factors in a general population of Bangladesh. Indian J Gastroenterol 2014;33:265-273.

22. Rasmussen S, Jensen TH, Henriksen SL, et al. Overlap of symptoms of gastroesophageal reflux disease, dyspepsia and irritable bowel syndrome in the general population. Scand J Gastroenterol 2015; 50:162-169.

23. Hongo M, Harasawa S, Mine T, et al. Large-scale randomized clinical study on functional dyspepsia treatment with mosapride or teprenone: Japan Mosapride Mega-Study (JMMS). J Gastroenterol Hepatol 2012;27:62-68.

24. Oshima T, Fukui H, Watari J, Miwa H. Childhood abuse history is associated with the development of dyspepsia: a population-based survey in Japan. J Gastroenterol Online First: 22 Nov 2014. doi: 10.1007/s00535-014-1014-3.

25. Oshima T, Miwa H. [Functional gastrointestinal disorders (FGID): progress in diagnosis and treatments. Topic I. Basic knowledge of functional gastrointestinal disorders (FGID); 1. Epidemiology of FGID.] Nihon Naika Gakkai Zasshi 2013;102:4-10. [Japanese]

26. Longstreth GF, Thompson WG, Chey WD, Houghton LA, Mearin F, Spiller RC. Functional bowel disorders. Gastroenterology 2006;130:1480-1491.

27. Saito YA, Schoenfeld P, Locke GR 3rd. The epidemiology of irritable bowel syndrome in North America: a systematic review. Am J Gastroenterol 2002;97:1910-1915.

28. Jung HK, Halder S, McNally $M$, et al. Overlap of gastro-oesophageal reflux disease and irritable bowel syndrome: prevalence and risk factors in the general population. Aliment Pharmacol Ther 2007;26:453-461.

29. Miwa H. Prevalence of irritable bowel syndrome in Japan: internet survey using Rome III criteria. Patient Prefer Adherence 2008;2: 143-147.

30. Gómez Alvarez DF, Morales Vargas JG, Rojas Medina LM, Mujica Oviedo SC, Camacho López PA, Rueda Jaimes GE. [Prevalence of irritable bowel syndrome and associated factors according to the Rome III diagnostic criteria in a general population in Colombia]. Gastroenterol Hepatol 2009;32:395-400. [Spanish]

31. Khoshkrood-Mansoori B, Pourhoseingholi MA, Safaee A, et al. Irritable bowel syndrome: a population based study. J Gastrointestin Liver Dis 2009;18:413-418.

32. Lee S, Wu J, Ma YL, Tsang A, Guo WJ, Sung J. Irritable bowel syndrome is strongly associated with generalized anxiety disorder: a community study. Aliment Pharmacol Ther 2009;30:643-651.

33. Sorouri M, Pourhoseingholi MA, Vahedi M, et al. Functional bowel disorders in Iranian population using Rome III criteria. Saudi J Gastroenterol 2010;16:154-160.

34. Ebling B, Jurcić D, Gmajnić R, Vcev A, Bilić A, Pribić S. Anthropological, demographic and socioeconomic characteristics of irritable bowel syndrome. Coll Antropol 2011;35:513-521.

35. Kubo M, Fujiwara Y, Shiba M, et al. Differences between risk factors among irritable bowel syndrome subtypes in Japanese adults. Neurogastroenterol Motil 2011;23:249-254.

36. Makharia GK, Verma AK, Amarchand R, et al. Prevalence of irritable bowel syndrome: a community based study from northern India. J Neurogastroenterol Motil 2011;17:82-87.

37. Krogsgaard LR, Engsbro AL, Bytzer P. The epidemiology of irritable bowel syndrome in Denmark. a population-based survey in adults $</=50$ years of age. Scand J Gastroenterol 2013;48:523-529.

38. Lin S, Mooney PD, Kurien M, Aziz I, Leeds JS, Sanders DS. Prevalence, investigational pathways and diagnostic outcomes in differing irritable bowel syndrome subtypes. Eur J Gastroenterol Hepatol 2014;26:1176-1180

39. Nakajima S, Takahashi K, Sato J, et al. Spectra of functional gastrointestinal disorders diagnosed by Rome III integrative questionnaire in a Japanese outpatient office and the impact of overlapping. J Gastroenterol Hepatol 2010;25(suppl 1):S138-S143.

40. Manabe N, Haruma K, Hata J, et al. Clinical characteristics of Japanese dyspeptic patients: is the Rome III classification applicable? Scand J Gastroenterol 2010;45:567-572.

41. Miwa H, Kusano M, Arisawa T, et al. Evidence-based clinical practice guidelines for functional dyspepsia. J Gastroenterol 2015; 50:125-139.

42. Kinoshita Y, Chiba T; FUTURE Study Group. Characteristics of Japanese patients with chronic gastritis and comparison with functional dyspepsia defined by ROME III criteria: based on the large-scale survey, FUTURE study. Intern Med 2011;50:2269-2276.

43. Park JM, Choi MG, Cho YK, et al. Functional gastrointestinal disorders diagnosed by Rome III questionnaire in Korea. J Neurogastroenterol Motil 2011;17:279-286.

44. Talley NJ, Zinsmeister AR, Schleck CD, Melton LJ 3rd. Dyspepsia and dyspepsia subgroups: a population-based study. Gastroenterology 1992;102(4 Pt 1):1259-1268.

45. Mahadeva S, Goh KL. Epidemiology of functional dyspepsia: a global perspective. World J Gastroenterol 2006;12:2661-2666.

46. Schlemper RJ, van der Werf SD, Vandenbroucke JP, Biemond I, Lamers CB. Peptic ulcer, non-ulcer dyspepsia and irritable bowel syndrome in The Netherlands and Japan. Scand J Gastroenterol Suppl 1993;200:33-41.

47. Corsetti M, Caenepeel P, Fischler B, Janssens J, Tack J. Impact of coexisting irritable bowel syndrome on symptoms and pathophysiological mechanisms in functional dyspepsia. Am J Gastroenterol 2004;99:1152-1159.

48. Olafsdottir LB, Gudjonsson H, Jonsdottir HH, Thjodleifsson B. Natural history of functional dyspepsia: a 10-year population-based study. Digestion 2010;81:53-61.

49. Ahlawat SK, Cuddihy MT, Locke GR 3rd. Gender-related differences in dyspepsia: a qualitative systematic review. Gend Med 2006; $3: 31-42$. 
50. Drossman DA, Whitehead WE, Camilleri M. Irritable bowel syndrome: a technical review for practice guideline development. Gastroenterology 1997;112:2120-2137.

51. Heitkemper MM, Chang L. Do fluctuations in ovarian hormones affect gastrointestinal symptoms in women with irritable bowel syndrome? Gend Med 2009;6(suppl 2):152-167.

52. Kanazawa M, Endo Y, Whitehead WE, Kano M, Hongo M, Fukudo S. Patients and nonconsulters with irritable bowel syndrome reporting a parental history of bowel problems have more impaired psychological distress. Dig Dis Sci 2004;49:1046-1053.

53. Kumano H, Kaiya H, Yoshiuchi K, Yamanaka G, Sasaki T, Kuboki T. Comorbidity of irritable bowel syndrome, panic disorder, and agoraphobia in a Japanese representative sample. Am J Gastroenterol 2004;99:370-376.

54. Hirakawa K, Adachi K, Amano K, et al. Prevalence of non-ulcer dyspepsia in the Japanese population. J Gastroenterol Hepatol 1999;14:1083-1087.

55. Aro P, Talley NJ, Agréus L, et al. Functional dyspepsia impairs quality of life in the adult population. Aliment Pharmacol Ther 2011;33:1215-1224.

56. Manabe N, Haruma K. Diagnosis and treatment of dyspeptic patients in Japan. J Gastroenterol Hepatol 2011;26(suppl 3):27-31.

57. Adeyemo MA, Spiegel BM, Chang L. Meta-analysis: do irritable bowel syndrome symptoms vary between men and women? Aliment Pharmacol Ther 2010;32:738-755.

58. Lovell RM, Ford AC. Global prevalence of and risk factors for irritable bowel syndrome: a meta-analysis. Clin Gastroenterol Hepatol 2012;10:712-721, e4.

59. Okami Y, Kato T, Nin G, et al. Lifestyle and psychological factors related to irritable bowel syndrome in nursing and medical school students. J Gastroenterol 2011;46:1403-1410.

60. Stanghellini V. Relationship between upper gastrointestinal symptoms and lifestyle, psychosocial factors and comorbidity in the general population: results from the Domestic/International Gastroenterology Surveillance Study (DIGEST). Scand J Gastroenterol Suppl 1999;231:29-37.

61. Westbrook JI, Talley NJ. Empiric clustering of dyspepsia into symptom subgroups: a population-based study. Scand J Gastroenterol 2002;37:917-923.

62. Li Y, Nie Y, Sha W, Su H. The link between psychosocial factors and functional dyspepsia: an epidemiological study. Chin Med J 2002;115:1082-1084.

63. Wigington WC, Johnson WD, Minocha A. Epidemiology of irritable bowel syndrome among African Americans as compared with whites: a population-based study. Clin Gastroenterol Hepatol 2005; 3:647-653.

64. Mullan A, Kavanagh P, O'Mahony P, Joy T, Gleeson F, Gibney $\mathrm{MJ}$. Food and nutrient intakes and eating patterns in functional and organic dyspepsia. Eur J Clin Nutr 1994;48:97-105.

65. Cuperus P, Keeling PW, Gibney MJ. Eating patterns in functional dyspepsia: a case control study. Eur J Clin Nutr 1996;50:520-523.

66. Niec AM, Frankum B, Talley NJ. Are adverse food reactions linked to irritable bowel syndrome? Am J Gastroenterol 1998;93: 2184-2190

67. Shinozaki M, Fukudo S, Hongo M, et al. High prevalence of irritable bowel syndrome in medical outpatients in Japan. J Clin Gastroenterol
2008;42:1010-1016.

68. Shepherd SJ, Parker FC, Muir JG, Gibson PR. Dietary triggers of abdominal symptoms in patients with irritable bowel syndrome: randomized placebo-controlled evidence. Clin Gastroenterol Hepatol 2008;6:765-771.

69. Ong DK, Mitchell SB, Barrett JS, et al. Manipulation of dietary short chain carbohydrates alters the pattern of gas production and genesis of symptoms in irritable bowel syndrome. J Gastroenterol Hepatol 2010;25:1366-1373.

70. Staudacher HM, Lomer MC, Anderson JL, et al. Fermentable carbohydrate restriction reduces luminal bifidobacteria and gastrointestinal symptoms in patients with irritable bowel syndrome. J Nutr 2012;142:1510-1518.

71. Halmos EP, Power VA, Shepherd SJ, Gibson PR, Muir JG. A diet low in FODMAPs reduces symptoms of irritable bowel syndrome. Gastroenterology 2014;146:67-75, e5.

72. Khan MA, Nusrat S, Khan MI, Nawras A, Bielefeldt K. LowFODMAP diet for irritable bowel syndrome: is it ready for prime time? Dig Dis Sci 2014;60:1169-1177.

73. Suchy FJ, Brannon PM, Carpenter TO, et al. NIH consensus development conference statement: lactose intolerance and health. NIH Consens State Sci Statements 2010;27:1-27.

74. Yang J, Deng Y, Chu H, et al. Prevalence and presentation of lactose intolerance and effects on dairy product intake in healthy subjects and patients with irritable bowel syndrome. Clin Gastroenterol Hepatol 2013;11:262-268, e1.

75. Levy RL, Jones KR, Whitehead WE, Feld SI, Talley NJ, Corey LA. Irritable bowel syndrome in twins: heredity and social learning both contribute to etiology. Gastroenterology 2001;121:799-804.

76. Bengtson MB, Ronning T, Vatn MH, Harris JR. Irritable bowel syndrome in twins: genes and environment. Gut 2006;55:1754-1759.

77. Locke GR 3rd, Zinsmeister AR, Talley NJ, Fett SL, Melton LJ 3rd. Familial association in adults with functional gastrointestinal disorders. Mayo Clin Proc 2000;75:907-912.

78. van der Veek PP, van den Berg M, de Kroon YE, Verspaget HW, Masclee AA. Role of tumor necrosis factor-alpha and interleukin-10 gene polymorphisms in irritable bowel syndrome. Am J Gastroenterol 2005;100:2510-2516.

79. Gonsalkorale WM, Perrey C, Pravica V, Whorwell PJ, Hutchinson IV. Interleukin 10 genotypes in irritable bowel syndrome: evidence for an inflammatory component? Gut 2003;52:91-93.

80. Villani AC, Lemire M, Thabane M, et al. Genetic risk factors for post-infectious irritable bowel syndrome following a waterborne outbreak of gastroenteritis. Gastroenterology 2010;138:1502-1513.

81. Kilpatrick LA, Labus JS, Coveleskie K, et al. The HTR3A polymorphism c. $-42 \mathrm{C}>\mathrm{T}$ is associated with amygdala responsiveness in patients with irritable bowel syndrome. Gastroenterology 2011;140: 1943-1951.

82. Yeo A, Boyd P, Lumsden S, et al. Association between a functional polymorphism in the serotonin transporter gene and diarrhoea predominant irritable bowel syndrome in women. Gut 2004;53:14521458.

83. Camilleri M, Busciglio I, Carlson P, et al. Candidate genes and sensory functions in health and irritable bowel syndrome. Am J Physiol Gastrointest Liver Physiol 2008;295:G219-G225.

84. Lesch KP, Bengel D, Heils A, et al. Association of anxiety-related 
traits with a polymorphism in the serotonin transporter gene regulatory region. Science 1996;274:1527-1531.

85. Holtmann G, Siffert W, Haag S, et al. G-protein beta 3 subunit 825 $\mathrm{CC}$ genotype is associated with unexplained (functional) dyspepsia. Gastroenterology 2004;126:971-979.

86. Camilleri CE, Carlson PJ, Camilleri M, et al. A study of candidate genotypes associated with dyspepsia in a U.S. community. Am J Gastroenterol 2006;101:581-592.

87. Oshima T, Nakajima S, Yokoyama T, et al. The G-protein beta3 subunit 825 TT genotype is associated with epigastric pain syndrome-like dyspepsia. BMC Med Genet 2010;11:13.

88. Tahara T, Arisawa T, Shibata T, et al. Homozygous $825 \mathrm{~T}$ allele of the GNB3 protein influences the susceptibility of Japanese to dyspepsia. Dig Dis Sci 2008;53:642-646.

89. van Lelyveld N, Linde JT, Schipper M, Samsom M. Candidate genotypes associated with functional dyspepsia. Neurogastroenterol Motil 2008;20:767-773

90. Andresen V, Camilleri M, Kim HJ, et al. Is there an association between GNbeta3-C825T genotype and lower functional gastrointestinal disorders? Gastroenterology 2006;130:1985-1994.

91. Toyoshima F, Oshima T, Nakajima S, et al. Serotonin transporter gene polymorphism may be associated with functional dyspepsia in a Japanese population. BMC Med Genet 2011;12:88.

92. Tahara T, Shibata T, Nakamura M, et al. Homozygous TRPV1 $315 \mathrm{C}$ influences the susceptibility to functional dyspepsia. J Clin Gastroenterol 2010;44:e1-e7.

93. Arisawa T, Tahara T, Shiroeda H, et al. Genetic polymorphisms of SCN10A are associated with functional dyspepsia in Japanese subjects. J Gastroenterol 2013;48:73-80.
94. Levy RL, Whitehead WE, Walker LS, et al. Increased somatic complaints and health-care utilization in children: effects of parent IBS status and parent response to gastrointestinal symptoms. Am J Gastroenterol 2004;99:2442-2451.

95. Dinan TG, Cryan J, Shanahan F, Keeling PW, Quigley EM. IBS: an epigenetic perspective. Nat Rev Gastroenterol Hepatol 2010;7: 465-471.

96. Talley NJ, Fett SL, Zinsmeister AR, Melton LJ 3rd. Gastrointestinal tract symptoms and self-reported abuse: a population-based study. Gastroenterology 1994;107:1040-1049.

97. Drossman DA, Talley NJ, Leserman J, Olden KW, Barreiro MA. Sexual and physical abuse and gastrointestinal illness. Review and recommendations. Ann Intern Med 1995;123:782-794.

98. Chitkara DK, van Tilburg MA, Blois-Martin N, Whitehead WE. Early life risk factors that contribute to irritable bowel syndrome in adults: a systematic review. Am J Gastroenterol 2008;103:765-774.

99. Talley NJ, Weaver AL, Zinsmeister AR, Melton LJ 3rd. Onset and disappearance of gastrointestinal symptoms and functional gastrointestinal disorders. Am J Epidemiol 1992;136:165-177.

100. Drossman DA, Morris CB, Hu Y, et al. A prospective assessment of bowel habit in irritable bowel syndrome in women: defining an alternator. Gastroenterology 2005;128:580-589.

101. Halder SL, Locke GR 3rd, Schleck CD, Zinsmeister AR, Melton LJ 3rd, Talley NJ. Natural history of functional gastrointestinal disorders: a 12-year longitudinal population-based study. Gastroenterology 2007;133:799-807.

102. Hongo M. Initial approach and pharmacotherapy for functional dyspepsia - a large clinical trial in Japan. Gastroenterology 2006; 130(suppl 2):A506. 